\title{
Biotic response to altered freshwater inflow patterns to the Kromme River Estuary, South Africa
}

\author{
T. H. Wooldridge \\ Department of Zoology, Nelson Mandela Metropolitan University, \\ Port Elizabeth, South Africa
}

\begin{abstract}
The Kromme is an example of an estuary where freshwater inflow is significantly attenuated. Completion of a second major dam in 1983 increased total dam storage capacity above the Mean Annual Runoff (MAR) from the catchment. Currently, less than $2 \%$ of MAR reaches the estuary. Marine dominance is now persistent with little upstream variation in water salinity. Amplitude and frequency of flood events have also declined and most of the smaller floods and freshettes no longer arrive at the estuary. Sediment dynamics have also changed, particularly in the lower reaches where less frequent scouring enables disproportionately large sandbanks to develop. These sandbanks are only removed by very large floods. Sediment accumulation in the lower estuary has reduced the efficiency of tidal exchange and this exacerbates high salinity in the upper reaches. Because of changes to natural patterns in the physico-chemical environment, floral and faunal characteristics of the estuary have shifted. Eelgrass (Zostera capensis) particularly, has become more extensive (a four-fold increase in biomass compared to the natural state) due to less frequent floods. These eelgrass beds constitute the most important habitat with respect to invertebrate production. Invertebrate species that favour vegetated areas (e.g. the shrimp Palaemon perengueyi) currently dominate the benthic community while species that favour non-vegetated sediments have probably declined (e.g. the mudprawn Upogebia africana).

Keywords: freshwater attenuation, dam, estuary, community changes.
\end{abstract}




\section{Introduction}

The completion in 1983 of a second major dam (Mpofu) on the Kromme River (Eastern Cape, South Africa), increased total storage capacity $\left(133 \times 10^{6} \mathrm{~m}^{3}\right)$ above Mean Annual Runoff (MAR) from the catchment (Bickerton and Pierce [1]). The dam is close to the coast $(18 \mathrm{~km}$ and only $4 \mathrm{~km}$ above the estuary) and now receives $<2 \%$ of MAR. Average salinity range along the estuary is $<5 \mathrm{psu}$ and the upper reaches become hypersaline in summer with salinity seldom falling below 30 psu in any part (Whitfield and Bruton [2], Baird and Heymans [3], Wooldridge [4]). The impoundments also reduce frequency and amplitude of flood events and this has modified sediment dynamics. Less river sediment now reaches the estuary; in contrast to the lower reaches where infrequent flood scouring enabled disproportionately large sand banks to develop (Reddering [5]). These sandbanks are only removed by very large floods. Increased sedimentation in the lower estuary has also reduced the efficiency of tidal exchange and this exacerbates hypersalinity in the upper reaches.

Although post-1983 conditions reflect strong marine dominance, research undertaken prior to 1983 suggests that widespread euhalinity was already prevalent in the Kromme estuary. These earlier studies documented increased marine influence in summer when hypersaline conditions developed in the upper reaches (Hecht [6], Baird et al. [7], Marais [8], Bickerton and Pierce [1]). Hanekom [9] recorded salinity values close to 35 during two consecutive summers, also noting the effects of four floods (July-August 1979 and March and June 1981) that flushed the estuary on each occasion. In 1979, surface salinity values in the upper reaches were still below 10 psu two months after the August flood (Hanekom [9]).

Available salinity data therefore suggest that in the 1970 s, euhalinity was already an intermittent feature of the Kromme estuary. The Churchill Dam (maximum capacity $33.3 \times 10^{6} \mathrm{~m}^{3}$ ) higher up in the catchment would also have exacerbated euhaline conditions, but there are no empirical data to evaluate its impact. However, recent hydrological modelling of the estuary provides some potential answers with respect to the salinity regime in the estuary prior to the construction of the dams. Information generated by the model suggests that the system naturally fluctuated between a marine dominated state and a situation where a salinity gradient existed under median flow conditions (Department of Water Affairs and Forestry [10]). In addition, the report [10] stated that 'major floods have been dramatically modified and most of the freshets and smaller floods do not reach the estuary'. Integration of empirical data and information from the model would suggest that marine dominance was not an unnatural feature of the estuary, although the persistence of high salinity has probably increased as a consequence of the larger downstream dam in particular. Reductions in estuarine water salinity are now of shorter duration and occur less frequently because of impoundment effects.

The current paper reviews historical research records on the biota of the Kromme estuary and attempts to evaluate changes in community composition 
and structure brought about by the construction of the Mpofu impoundment completed in 1983 .

\section{Characteristics of the Kromme River and Estuary}

The Kromme River rises some 95 kilometres from the sea in the Langkloof Valley between the coastal Tsitsikamma Mountains and the Kouga range. Quartzite forms the largest part of the geological substrate in the catchment basin; the total area varying between $936 \mathrm{~km}^{2}$ and $1125 \mathrm{~km}^{2}$, depending on the source reference (Bickerton and Pierce [1]).

Rainfall in the Kromme catchment is distributed throughout the year with spring and autumn peaks. Mean annual precipitation varies from 700 to 1200 $\mathrm{mm}$. Flow patterns in the Kromme are erratic and floods have occurred in almost every month of the year (Bickerton and Pierce [1]).

The $13.7 \mathrm{~km}$ long estuary has an approximate surface area of $300 \mathrm{ha}$. The estuary has one major tributary, the Geelhoutboom (fig. 1). Although constricted, the tidal inlet remains permanently open to the sea. Tides are semi-diurnal with a small diurnal inequality. Mean spring tide range outside the inlet is about 1.75 $\mathrm{m}$, while neap tides average $0.57 \mathrm{~m}$. A flood tidal delta extends $5 \mathrm{~km}$ from the mouth, but additional sand is derived from an adjacent dunefield. In the upper reaches the estuary in narrow and incised into bedrock. The lower estuary is shallow ( $<2 \mathrm{~m}$ depth); upstream water depth averages 3-4 $\mathrm{m}$ in channel areas. Other physical characteristics of the estuary are given in Table 1.

Table 1: Physical characteristics of the Kromme estuary. Data from Baird and Ulanowicz [11] and Bickerton and Pierce [1].

\begin{tabular}{|c|c|c|c|}
\hline Length $(\mathrm{km})$ & Width $(\mathrm{m})$ & Depth $(\mathrm{m})$ & Tidal prism \\
\hline 13.7 & $\begin{array}{c}\text { Maximum 175 } \\
\text { Average 80 }\end{array}$ & $\begin{array}{c}\text { Maximum 5 } \\
\text { Average 2.5 }\end{array}$ & $1.87 \times 10^{6} \mathrm{~m}^{3}$ \\
\hline
\end{tabular}

The Geelhoutboom tributary rises in the Humansdorp area where the underlying geological formation is Bokkeveld slate that is readily eroded (Reddering and Esterhuysen [12]). Consequently, the Geelhoutboom River carries a relatively high sediment load when it enters the estuary about $8 \mathrm{~km}$ from the mouth. On occasions, fine sediment loading of the Geelhout tributary is exacerbated by runoff from farmlands adjacent to the river and estuary (fig. 1).

Sediments in the Kromme estuary become progressively finer-grained in an upstream direction, mainly because of the decreasing velocity of tidal currents (Reddering and Esterhuysen [12]). The fine muddy sediments in the middle and upper estuary have a fluvial origin, although the two large storage reservoirs probably stop most fluvial sediment input via the main tributary. Sediment input via the Geelhoutboom tributary will not be influenced by the reservoirs and fine material continues to be deposited into the estuary. According to Reddering and Esterhuysen [12], the mixing of marine sand and mud results in a compact mass that is not easily removed by floods. 


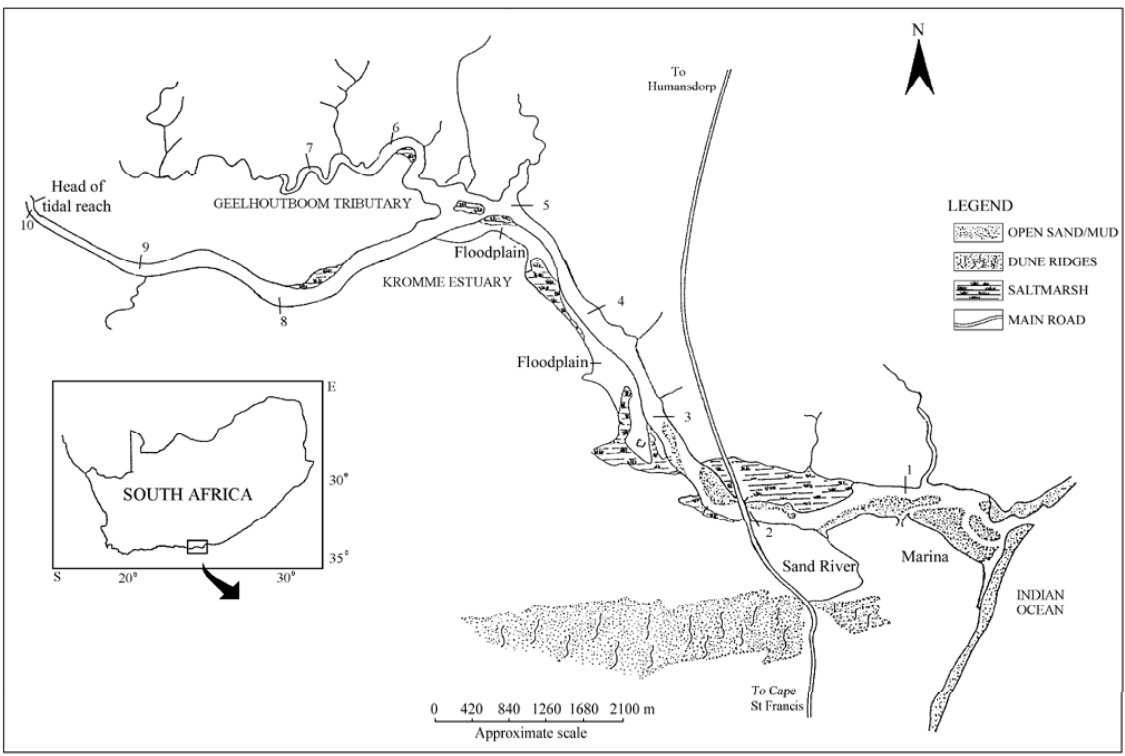

Figure 1: $\quad$ Map of the Kromme River Estuary and Geelhout tributary.

The lower reach of the estuary (ca $5 \mathrm{~km}$ ) is relatively shallow and sandy with well-developed intertidal flats (fig. 1). This section of the estuary is very dynamic and channels continually change their position. Most of this sand is of marine origin. A further source of sand influx is via the Sand River that enters the estuary approximately $2 \mathrm{~km}$ from the mouth (fig. 1). The Sand River drains an extensive dune field to the southwest and carries sand into the lower estuary during occasional floods.

\section{Present freshwater supply to the estuary}

Present management policy provides for a total annual freshwater allocation of $2 \times 10^{6} \mathrm{~m}^{3}$ for the estuary, unless natural overtopping of the dam occurs. However, overtopping is infrequent, and years may pass between overspill events. Severe drought at the end of the 1980s and early 1990s resulted in the reservoir levels falling below $30 \%$ of capacity (Jury and Levey [13]). Freshwater was then released on a monthly basis $\left(1 / 12 \times 2 \times 10^{6} \mathrm{~m}^{3}\right)$ in order to prevent hypersalinity developing in the upper estuary.

During the latter part of the drought (early 1990s) and up to the present time, no regular freshwater releases are made for environmental purposes. Consequently, river flow below the Mpofu dam is erratic and the estuary received little or no freshwater, except for local runoff after very heavy rains. Because the Mpofu Dam reduces natural runoff from the catchment, marine conditions in the estuary now persist for extended periods (years). 


\section{The influence of river impoundment on the macrophyte Zostera capensis}

No spatial separation of macrophyte communities along the length of the Kromme estuary is apparent, although some variation occurs. This is due to the absence of a salinity gradient that normally structures the species composition as salinity decreases upstream (Adams et al. [14]). For example, Zostera capensis (eelgrass) currently extends into the upper reaches in comparison to its usual association with lower reaches of estuaries. During the period 1983 to 1992, Adams and Talbot [15] registered a four-fold increase in the standing biomass of eelgrass. This was primarily ascribed to reduced inflow of freshwater after construction of the dam, lack of sedimentary disturbances, stable salinity values and reduced turditities. Talbot et al. [16] consider flooding and associated sedimentary effects to be the over-riding forcing function determining the state of submerged macrophytes in small estuaries subject to occasional floods.

\section{Changes in the macrobenthic community after the construction of the Mpofu dam $4 \mathrm{~km}$ above the estuary}

Fifty-six macrobenthic species are listed by Bickerton and Pierce [1] in the Kromme estuary. These results are based on earlier studies by numerous researchers. The sandprawn Callianassa kraussi is one of the most widespread species, attaining densities of over 100 individuals per $\mathrm{m}^{2}$ of substrate above the roadbridge (Day [17]). This species is relatively scarce in the sands at the mouth where it is replaced by a high density $\left(136\right.$ per $\left.^{2}\right)$ of Loripes clausus (Hecht 1973, quoted in Emmerson et al. [18]).

The mudprawn Upogebia africana, occurs upstream of the bridge where a muddy substratum is present. In places, density exceeds 100 individuals per $\mathrm{m}^{2}$ (Day [17]). The crab Sesarma catenata is common in areas where saltmarsh occurs. Submerged Zostera beds (eelgrass) along the main estuary also harbour a rich and abundant fauna (Emmerson et al. [18], Hanekom [9]). Emmerson et al. [18] listed dominant species present in eelgrass beds that included the molluscs Arcuatula capensis (max. 469 individuals per $\mathrm{m}^{2}$ ), Macoma litoralis (max. 181 individuals per $\mathrm{m}^{2}$ ) and Nassarius kraussianus (max. 241 individuals per $\mathrm{m}^{2}$ ), as well as crustaceans such as Cleistostoma edwardsii and C. algoense (max. 296 and 156 individuals per $\mathrm{m}^{2}$ respectively).

Hanekom [9] recorded 29 macrobenthic species using a $1 \mathrm{~mm}$ mesh sieve in intertidal Zostera beds. Thirteen of the species were crustaceans and 12 were molluscs. In addition, Hanekom [9] sampled non-vegetated areas adjacent to Zostera beds. Most species occurred in both habitats, but the isopod Exosphaeroma hylocoetes, the molluscs Arcuatula capensis, Haminea alfredensis and Natica tecta were found only at sites covered with Zostera. Other species such as the polychaete worm Ceratonereis erythraeensis, the crabs Cleistostoma edwardsii and Hymenosoma orbiculare were also more abundant in 
vegetated areas. The mudprawn Upogebia africana on the other hand, was more common in open areas.

The general distribution of the 29 species recorded by Hanekom [9] along the length of the Kromme estuary was similar to that recorded by Hecht [6] who sampled in Zostera and non-Zostera areas. No one species was present at all sites, although the crown-crab Hymenosoma orbiculare, the bivalve Macoma littoralis and the crab Cleistostoma edwardsii occurred at most sites. Species such as Alpheus crassimanus, Betaeus jucundus, Loripes clausus, Polybranchiorhynchus dayi and Solen capensis were relatively rare $(<10 \%$ of sites sampled).

Decapod crustaceans Cleistostoma edwardsii and Upogebia africana tended to dominate lower and lower-middle reaches, but upper reaches were dominated by a mollusc community (Arcuatula capensis, Macoma litoralis, Solen cylindraceus and Nassarius kraussianus). The crown crab Hymenosoma orbiculare was more or less evenly distributed along the estuary. Bivalves such as Loripes clauses and Solen capensis were limited to the mouth region.

Winter and Baird [19] have underlined the importance of anomuran, brachyuran and macruran crustaceans in controlling energy flow in many Eastern Cape estuaries, including the Kromme. The most important of these species from an energy flow perspective is the shrimp Palaemon perengueyi (Table 2). Palaemon peringueyi occurs primarily in subtidal eelgrass habitat (Emmerson [20]) and attains extremely high densities (max. 1016 individuals per $\mathrm{m}^{2}$ ) (Emmerson et al. [21]). This species breeds in nearshore oceanic waters and postlarvae then migrate into estuaries or pools along the intertidal rocky shore where they utilize available resources. Table 2 below ranks the five most important species with respect to energy flow in the Kromme estuary.

Table 2: Contribution to annual production of the five most important invertebrates present in the Kromme estuary prior to the construction of the $2^{\text {nd }}$ dam in 1983 (extracted from Winter and Baird [19]).

\begin{tabular}{|l|c|}
\hline \multicolumn{1}{|c|}{ Species } & $\begin{array}{c}\text { Contribution to macroinvertebrate } \\
\text { production (\%) }\end{array}$ \\
\hline Palaemon perengueyi & 32 \\
\hline Sesarma catenata & 22 \\
\hline Upogebia africana & 13 \\
\hline Macoma litoralis & 10 \\
\hline Callianassa kraussi & 8 \\
\hline
\end{tabular}

The five major producers contributed $85 \%$ to total production. Although the total number of species recorded was much higher, the data reflected the importance of a few key species. In terms of habitat, benthic macroinvetebrate 
production was greatest in Zostera capensis beds (35.2\%), followed by saltmarsh and mud habitats (each 25.2\%) (Winter and Baird [19]). Thus, 85\% of macroinvertebrate production in the Kromme estuary was associated with nonsandy habitats upstream of the mouth area where Zostera capensis was most prevalent.

In terms of freshwater reduction to estuaries, changes in the biota do not lead to changes in trophic levels, but rather to major shifts in the primary producers and trophic pathways (Grange et al. [22]). In the Kromme estuary, Baird and Heymans [3], report that there was a major decline in the zooplankton standing stock as a consequence of reduced phytoplankton stock after 1983 when the dam was built. Submerged macrophyte biomass on the other hand increased from 60 to $125 \mathrm{~g} \mathrm{C} \mathrm{m}^{-2}$, leading to changes in the balance between primary producers. This is supported by Adams and Talbot [15] who recorded a four-fold increase in standing biomass of Zostera capensis in the nine-year period after construction of the Mpofu dam. This included a 2.4 fold increase in density and a 1.6 fold increase in aerial coverage.

Table 3: $\quad$ Predicted change in the standing stock of key macrobenthic species after the construction of the Mpofu dam in 1983. The predicted change is based on habitat preference of the species (see text) and the four-fold increase in Zostera capensis standing stock in the estuary. (+) indicates an increase in standing stock, (-) indicates a decrease in standing stock.

\begin{tabular}{|l|c|l|}
\hline \multicolumn{1}{|c|}{ Species } & Predicted change & \multicolumn{1}{c|}{ Reference source } \\
\hline Upogebia africana & - & Hanekom [9] \\
\hline Exosphaeroma hylecoetes & + & Hanekom [9] \\
\hline Palaemon perengueyi & + & Emmerson et al. [21] \\
\hline Cleistostoma edwardsii & + & Hanekom [9] \\
\hline Hymenosoma orbiculare & + & Hanekom [9] \\
\hline Arcuatula capensis & + & Hanekom [9] \\
& + & Emmerson et al. [21] \\
\hline Haminea alfredensis & + & Hanekom [9] \\
\hline Natica tecta & + &
\end{tabular}

Increase in $Z$. capensis density and coverage after dam construction would also have led to changes in zoobenthic community structure. Predicted shifts in population abundance levels and contribution to invertebrate production for some of the important benthic species are listed in Table 4. These predicted shifts are based on habitat preference already discussed. Palaemon perengueyi for example, occurs primarily in eelgrass beds (Emmerson [20]) and the increase 
in $Z$. capensis density and coverage would therefore have favoured an increase in $P$. perengueyi biomass, a species responsible for about $32 \%$ of invertebrate annual production (Table 2) in the Kromme estuary before 1983. Thus, abundance and proportional contribution of $P$. perengueyi to production is also likely to have increased. Similarly species that prefer non-vegetated habitats along the intertidal and marginal fringes would have responded negatively to an increase in Zostera capensis biomass (e.g. the mudprawn Upogebia Africana).

\section{Conclusion}

Construction of a second major dam in 1983 on the Kromme River increased total reservoir storage capacity above Mean Annual Runoff (MAR) from the catchment. Although marine dominance was not an unnatural feature of the estuary, the persistence of high salinity has increased. Reductions in estuarine water salinity are now of shorter duration and occur less frequently because of impoundment effects. These impoundments also reduce frequency and amplitude of flood events. As a consequence of a less variable salinity regime, reduced sedimentary disturbance and reduced turbidity, eelgrass (Zostera capensis) distribution and coverage has expanded, with biomass increasing fourfold. This has led to structural and functional changes in the invertebrate community. Zooplankton biomass has declined while biomass of benthic species and their relative importance as contributors to invertebrate production in the estuary has probably increased significantly (e.g. Palaemon perengueyi). By contrast, intertidal mudbanks have decreased in area (increased Zostera capensis coverage) and this has probably led to a decline in biomass of species inhabiting these open habitats (e.g. Upogebia africana).

\section{References}

[1] Bickerton, I.B. \& Pierce, S. M., Estuaries of the Cape. PartII. Synopsis of available information on individual systems, Report No. 33: Krom (CMS 45), Seekoei (CMS 46) and Kabeljous (CMS 47), eds. A.E.F. Heydorn. \& P.D. Morant, CSIR Research Report432, Stellenbosch, pp. 1-109, 1988.

[2] Whitfield, A.K. \& Bruton, M.N., Some biological implications of reduced fresh water inflow into Eastern Cape estuaries: a preliminary assessment. South African Journal of Science, 85, pp. 691-694, 1989.

[3] Baird, D. \& Heymans, J.J., Assessment of ecosystem changes in response to freshwater inflow of the Kromme estuary, St Francis Bay, South Africa: a network analysis approach. WaterSA, 22, pp. 307-317, 1996.

[4] Wooldridge, T.H., Estuarine zooplankton community structure and dynamics (Chapter 7). Ecology of South African Estuaries, eds. B. Allanson \& D. Baird, Cambridge University Press, UK, pp. 141-166, 1999.

[5] Reddering, J.S.V., Prediction of the effects of reduced river discharge on the estuaries of the south-eastern Cape Province, South Africa. South African Journal of Science, 84, pp. 726-730, 1988. 
[6] Hecht, T., The ecology of the Kromme River Estuary with special reference to Sesarma catenata. Unpublished MSc dissertation, University of Port Elizabeth, pp. 1-150, 1973.

[7] Baird, D., Marais, J.F.K. \& Wooldridge, T.H., The influence of a marina canal system on the ecology of the Kromme Estuary, St Francis Bay. South African Journal of Zoology, 16, pp. 21-24, 1981.

[8] Marais, J.F.K., Seasonal abundance, distribution and catch-per-unit-effort of fishes in the Kromme estuary, South Africa. South African Journal of Zoology, 18, pp. 96-102, 1983.

[9] Hanekom, N., An ecological study of the Zostera beds in the Kromme Estuary. University of Port Elizabeth Report No. 18, pp. 1-163, 1982.

[10] Department of Water Affairs and Forestry, South Africa, Kromme/Seekoei Catchments Reserve Determination study - technical component. Kromme Estuary. Prepared by CSIR for Coastal and Environmental Services, Report RDM/EWR001/ER0005/CON/CES/1105, pp. 1-135, 2005.

[11] Baird, D. \& Ulanowicz, R.E., A comparative study of the trophic structure, cycling and ecosystem properties of four tidal estuaries. Marine Ecology Progress Series, 99, 221-237, 1993.

[12] Reddering, J.S.V. \& Esterhuysen, K., Sedimentation in the Kromme estuary. University of Port Elizabeth, ROSIE Report No. 6, pp. 1-92. 1983.

[13] Jury, M.R. \& Levey, K., The Eastern Cape drought. Water SA, 19, pp. 133-137, 1993.

[14] Adams, J.B., Knoop, W.T. \& Bate, G.C., The distribution of estuarine macrophytes in relation to freshwater. Botanica Marina, 35, pp. 215-226, 1992.

[15] Adams, J.B. \& Talbot, M.M.B., The influence of river impoundment on the estuarine seagrass Zostera capensis Setchell. Botanica Marina, 35, pp. 69-75, 1992.

[16] Talbot, M.M.B., Knoop, W.T. \& Bate, G.C., The dynamics of estuarine macrophytes in relation to flood/siltation cycles. Botanica Marina, 33, pp. 159-164, 1990.

[17] Day, J.H., Summaries of current knowledge of 43 estuaries in southern Africa (Chapter 14). Estuarine ecology with particular reference to southern Africa, ed. J.H. Day, A.A. Balkema, Cape Town, pp. 251-329, 1981.

[18] Emmerson, W.D., Watling, H.R. \& Watling R.J., Community analyses in the Kromme and Swartkops estuaries and in the Algoa Region. University of Port Elizabeth Zoology Department Report Series No. 16, pp. 1-128, 1982.

[19] Winter, P.E.D. \& Baird, D., Diversity, productivity, and ecological importance of macrobenthic invertebrates in selected Eastern Cape Estuaries (Chapter 15), Towards an environmental plan for the Eastern Cape, ed. M.N. Bruton \& F.W. Gess, Grocott \& Sherry, Grahamstown, pp. 149-154, 1988. 
[20] Emmerson, W.D., The ecology of Palaemon pacificus (Stimpson) associated with Zostera capensis Setchell. Transactions of the Royal Society of South Africa, 46, pp. 79-97, 1986.

[21] Emmerson, W.D., Watling, H.R. \& Watling R.J., Community analyses in the Kromme and Swartkops estuaries and in the Algoa region, University of Port Elizabeth Zoology Department Report Series, No. 16, pp. 1-128, 1982.

[22] Grange, N., Whitfield, A.K., De Villiers, C.J. \& Allanson, B.R., The response of two South African east coast estuaries to altered river flow regimes, Aquatic Conservation: Marine and Freshwater Ecosystems, 10, pp. 155-177, 2000.

[23] Jerling, H.L. \& Wooldridge, T.H., The mesozooplankton of a freshwaterstarved estuary, Changes in fluxes in estuaries: implications from Science to Management, eds K.R. Dyer \& R.J. Orth, Olsen \& Olsen, Fredensborg, Denmark, pp. 301-306, 1994. 